
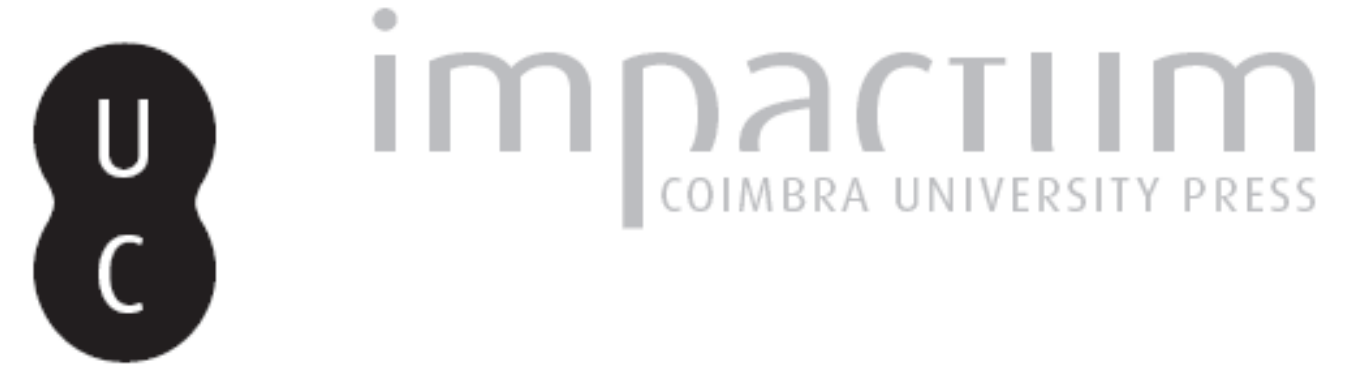

\title{
La condición fascista de la dictadura franquista treinta y cinco años después
}

Autor(es): $\quad$ Rodríguez Gallardo, Ángel

Publicado por: Faculdade de Letras, Instituto de História Económica e Social

URL persistente:

URI:http://hdl.handle.net/10316.2/11980

DOI:

DOI:http://dx.doi.org/10.14195/0870-4147_40_16

Accessed : $\quad$ 26-Apr-2023 08:59:06

A navegação consulta e descarregamento dos títulos inseridos nas Bibliotecas Digitais UC Digitalis, UC Pombalina e UC Impactum, pressupõem a aceitação plena e sem reservas dos Termos e Condições de Uso destas Bibliotecas Digitais, disponíveis em https://digitalis.uc.pt/pt-pt/termos.

Conforme exposto nos referidos Termos e Condições de Uso, o descarregamento de títulos de acesso restrito requer uma licença válida de autorização devendo o utilizador aceder ao(s) documento(s) a partir de um endereço de IP da instituição detentora da supramencionada licença.

Ao utilizador é apenas permitido o descarregamento para uso pessoal, pelo que o emprego do(s) título(s) descarregado(s) para outro fim, designadamente comercial, carece de autorização do respetivo autor ou editor da obra.

Na medida em que todas as obras da UC Digitalis se encontram protegidas pelo Código do Direito de Autor e Direitos Conexos e demais legislação aplicável, toda a cópia, parcial ou total, deste documento, nos casos em que é legalmente admitida, deverá conter ou fazer-se acompanhar por este aviso.

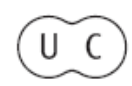



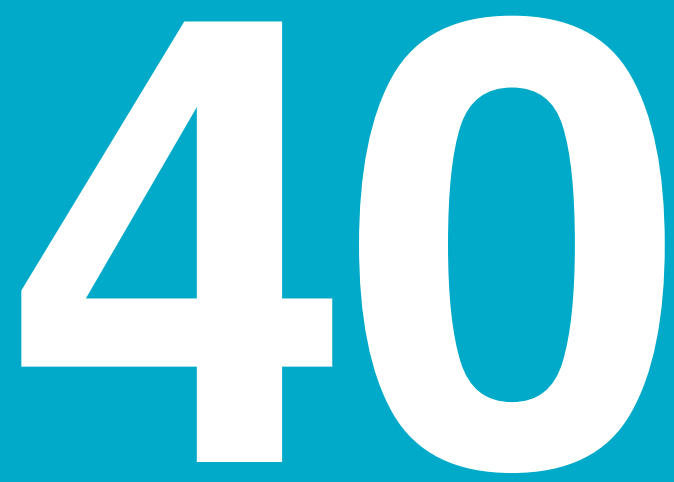

\section{Revista Portuguesa de História}

Faculdade de Letras da Universidade de Coimbra Instituto de História Económica e Social

Coimbra 08/09 


\title{
La condición fascista de la dictadura franquista treinta y cinco años después*
}

\author{
Ángel Rodríguez Gallardo \\ Investigador CEIS20 - Universidade de Coimbra
}

\section{Introducción}

En este trabajo reflexionamos sobre algunos aspectos de la dictadura franquista (1936-1975) una vez que han pasado treinta y cinco años del fin de la misma. En concreto, repasamos el tipo de reconocimiento político que se le ha adjudicado a la dictadura en la sociedad española y el tipo de «memoria científica» creada sobre Franco y el franquismo.

Todavía sigue siendo mayoritaria la identificación del régimen con la figura del «caudillo». Ese hecho ha uniformizado y extendido la denominación de «franquismo» frente a otras posibles que definitivamente no se han impuesto. Esa personalización no se produjo en el caso de los regímenes italiano o alemán, donde son excepcionales los términos «mussolinismo» 0 «hitlerismo». En esos países es más habitual la denominación «fascismo» como referencia a las experiencias históricas de sus regímenes políticos durante los años veinte y treinta del siglo $\mathrm{XX}^{1}$. En el caso español, como ha señalado Navarro (2006),

Este trabajo fue presentado y discutido en el curso de $2^{\circ}$ ciclo de Historia Contemporânea «Economia, Sociedade e Relações Internacionais» (FLUC, 2009). 
existe escasa predisposición en la opinión pública (medios de comunicación y medios académicos en tareas divulgativas), para emplear el término «fascismo» en relación a la dictadura franquista española. Según ese autor, esa denominación de fascismo para la dictadura franquista es habitual en los países nórdicos, en los Estados Unidos o en Gran Bretaña, y lo fue en la Europa de los años 40 o 50 del siglo pasado 2 . También el «Estado Novo» portugués era una modalidad más del fascismo, pero la eficacia con que el sistema salazarista fue presentado y defendido ante la opinión pública internacional hizo que periódicos como $L e$ Monde lo contemplasen en las últimas décadas como una «dictadura sabia y paternal» (Torgal, 2008: 21) ${ }^{3}$.

Es posible que el hecho de que en los círculos académicos se mantenga abierto el debate sobre la condición fascista de la dictadura franquista resulte un freno para la transmisión de una memoria de la política franquista como la propia de un régimen fascista ${ }^{4}$. Es posible también que el debate académico

1 De hecho, se tiende a limitar a esos países, o como mucho a Japón, el concepto de «régimen fascista» (Hernández Sandoica, 1992: 16).

2 En realidad, habría que matizar esta afirmación de Navarro. A partir de 1945 el régimen franquista utilizó los servicios de propaganda para construir un discurso mitificado en relación a Franco, incidiendo en sus dotes de estratega, en su instinto de salvador de la patria española, en su disposición para socorrer a los judíos y, en especial, en su decisión de dinamizar económicamente la sociedad española. Esa «buena prensa» se ha mantenido en los medios de comunicación anglosajones, aunque no en los medios académicos.

3 Así mismo este autor apunta que «não se criou uma memoria, por assim dizer, "científica" sobre Salazar e o Salazarismo, assim como não se criou uma memoria do mesmo tipo sobre o Estado Novo" (Torgal, 2008: 23).

${ }^{4}$ Los especialistas han venido dialogando y debatiendo sobre la conceptualización del régimen franquista, de modo que ha sido calificado de «dictadura militar de poder personal» o «dictadura caudillista» (Miguel y Oltra, 1978; Ferrando Badía, 1984; Aróstegui, 1986: 102; Juliá, 1993: 123-125; Elorza, 1996: 49), «dictadura fascista/totalitaria» (Ramírez, 1978; Tuñón de Lara y Biescas, 1980; Preston, 1986; Casanova, 1992), «régimen autoritario» (Linz, 1964, 1970, 1974 y 1978; Miguel, 1975; Payne, 1987; Tusell, 1988 y 2005), «régimen fascistizado» (Saz Campos, 1993; Saz Campos, 1996), «dictadura de mando personal» (Fusi, 1985: 72), «despotismo moderno» (Giner, 1985: 141) y «una versión diluida del fascismo» (Luebbert, 1997: 482). Las primeras respuestas a la tesis de «régimen autoritario» de Linz señalaron la condición de «dictadura» para el franquismo: Martínez Alier, J., "Contra la reconciliación”, Cuadernos de Ruedo Ibérico, 43/45, 1975, pp. 27-81; Carreras, J. J., "El franquismo, ¿un régimen autoritario?”, Andalán, 85, 1976, p. 13; Ruiz, D., La dictadura franquista, 1939-1975, Naranco, Oviedo, 1978; Tuñón de Lara, M. y otros, De la crisis del Antiguo Régimen al franquismo. Ideología y Sociedad en la España Contemporánea. Por un análisis del franquismo. VI Coloquio de Pau, Edicusa, Madrid, 1977. De algún modo todas estas conceptualizaciones pueden reagruparse en dos posiciones teóricas sobre la naturaleza del franquismo como régimen político. Por un lado, los que mantienen que fue un caso extremo de dictadura militar; por otro, los que creen en una versión española de un nuevo movimiento fascista. 
sobre la condición fascista de la dictadura franquista propiciado en su mayoría por camadas provenientes de las generaciones criadas durante el franquismo haya podido tener influencia en la negación, relativización u objeción de la consideración fascista del franquismo ${ }^{5}$.

Con cierta insistencia, Navarro (2006: 126) ha descrito la existencia de un proyecto político e intelectual que ha tenido un significativo éxito en España ${ }^{6}$. Este proyecto ha conseguido negar el carácter fascista de la dictadura franquista o, cuando menos, reducir su ámbito a los primeros años cuarenta del siglo XX, en especial al hilo de las coyunturas bélicas de la Segunda Guerra Mundial ${ }^{7}$. Según esta propuesta, el régimen fue inicialmente fascista y luego se transformó en otro autoritario bajo las directrices de un militar ${ }^{8}$. Por tanto, según esta perspectiva, no se puede hablar de un régimen totalitario, es decir, de un régimen que ordenase la sociedad dentro de una ideología totalizadora ${ }^{9}$.

Esta tesis del régimen franquista como «no fascista» ha sido defendida por los sectores conservadores de la sociedad española (el Partido Popular, medios de comunicación conservadores, una significativa parte de la sociedad $)^{10}$.

5 Buena parte de los historiadores o científicos sociales responsables de algunos de los estudios sobre la dictadura franquista crecieron y se educaron dentro de ese régimen. El papel de esa generación fue fundamental durante el franquismo, sobre todo a partir de los primeros conflictos universitarios en los años 50 del siglo XX. Fueron ellos los primeros en distanciarse del legado histórico franquista (Aguilar, 2008: 33-34, n. 12).

6 Otras intervenciones similares de este autor en El País de Catalunya, 17-12-2008, "Spain is different o la impunidad mantenida"; Diario Digital El Plural, 15-3-2010, "Las consecuencias de la transición inmodélica: el Tribunal Supremo".

7 Por ejemplo es lo que puede verse en autores como Rodríguez Jiménez (1997: 263 y ss.) y Núñez Seixas (2005: 22).

8 Aunque los especialistas discrepan en relación a la periodización de la dictadura franquista, Moradiellos (2004: 24-27) ha sintetizado las diversas posiciones existentes al establecer cinco etapas en la dictadura franquista: 1) 1936-1939, como etapa de configuración inicial del régimen durante la guerra civil, 2) 1939-1945, considerado el periodo nacional-sindicalista durante la Segunda Guerra Mundial, 3) 1945-1959, la etapa nacional-católica de aislamiento y posterior reintegración internacional, 4) 1959-1969, la etapa autoritaria de desarrollismo tecnocrático y expansión económica, 5) 1969-1975, el tardofranquismo y la crisis terminal del régimen.

9 Aunque casi todos los autores reconocen que el ideario totalitario estaba en los inicios del régimen a imitación del ideario italiano o alemán.

${ }^{10}$ En opinión de Navarro (2006), existen dos interpretaciones mayoritarias sobre el pasado franquista. En una de ellas, tanto el golpe militar de 1936 como la dictadura fueron procesos necesarios en el restablecimiento de un orden que se había perdido durante el periodo de la Segunda República (1931-1936). Los exégetas de esta visión entienden que la represión fue excesiva, que la dictadura se alargó más tiempo del debido, pero en cambio tienden a ver elementos positivos en ella. Además, creen que la democracia parlamentaria establecida por el rey Juan Carlos como heredero del general Franco se debe entender como una abertura de las instituciones estatales conservadoras a las fuerzas de izquierda y a los nacionalismos periféricos. Una segunda 
En realidad, las características del régimen franquista - como las de otros regímenes fascistas - lo convierten en un régimen con una importante capacidad de adaptación. La base fascista del régimen era "un fenómeno peculiarmente hispánico resultante de las condiciones existentes en España y de los sentimientos de los españoles", ha dicho hace años Payne (1986: 9). La influencia que el fascismo español recibió de la tradición nacionalcatólica recondujo parte de su ideario dentro de esa tradición con un "lenguaje más o menos fascistizado" (Saz, 2003: 54).

Cuando varió el rumbo de la Segunda Guerra Mundial a partir de la entrada de los Estados Unidos en el bando aliado en diciembre de 1941, posteriormente con el desembarco de las fuerzas aliadas en Sicilia ya en julio de 1943 y la destitución de Mussolini pocos días después, Franco retiró la presencia de la División Azul de la URSS y se concentró en "sobrevivir al fascismo en Europa", de modo que la propaganda del régimen procuró presentarlo como un "estadista neutral e imparcial que había sabido librar a España del desastre de la Segunda Guerra Mundial". A partir de ahí, el régimen se desprendió de la superficie fascista y subrayó el fondo católico para entroncarse con la tradición hispana (Casanova y Gil Andrés, 2009: 247-248). Este análisis se ha convertido en un lugar común dentro de la consideración sociopolítica del régimen franquista, de modo que no existe discrepancia en la interpretación fascista del periodo 1936$-1945^{11}$. Sin embargo, dada la duración del franquismo, muchos especialistas tienden a restar valor a ese periodo a través de una visión ideológica y política centrada en varios aspectos católicos, tradicionalistas y económicos, de forma que se anule la base fascista del régimen ${ }^{12}$.

interpretación alude a la guerra civil como un conflicto fratricida que se sustenta en la tesis de la supuesta tendencia hispánica a la violencia. De este modo, las consecuencias del conflicto deben compartirse. La Constitución española de 1978 cierra definitivamente la tradicional división de la dos Españas, aunque se reconoce la marginalidad histórica en la que han vivido los vencidos de la guerra civil. Navarro defiende que estas dos tesis son mayoritarias en la sociedad española y ello es debido al predominio de las fuerzas conservadoras en la sociedad española.

${ }^{11}$ El proceso de fascistización del régimen franquista se iniciaría durante la guerra civil (1936-1939) en los territorios controlados por Franco, para continuar en el periodo de posguerra (1939-1945). Según esta tesis, el régimen se iría desfascistizando a partir de 1945 por la presión internacional, de modo que adoptaría la forma de una «democracia orgánica y católica». La Ley de Sucesión a la Jefatura del Estado de 1947 se transformó en una especie de constitucionalismo cosmético en forma de evolución hacia una monarquía.

${ }^{12}$ El periodo 1945-1959 supuso un proceso de desfascistización aparente del régimen franquista a través de la eliminación de los símbolos fascistas y, sobre todo, de un programa propagandístico centrado en la regularización de las relaciones diplomáticas con la ONU y con los Estados Unidos. 
Incluso una vez el régimen ha sido superado desde el punto de vista social y su legado ha pasado aparentemente solo al desván de la historia, nunca se ha podido eliminar a lo largo del periodo democrático, la representación que sobre Franco y el franquismo se instaló en la mentalidad de muchos españoles. En ocasiones, de modo nada discreto y no intencional, reaparece la figura de un militar severo y paternal, en cuyo régimen muchas familias vivieron «con mucha naturalidad y tranquilidad», porque la dictadura ha llegado a ser contemplada décadas después como un periodo de «extraordinaria placidez» por algún significado político español ${ }^{13}$. Posiblemente esté funcionando un mecanismo discursivo superficial que haya establecido una consideración colectiva no estrictamente negativa del régimen franquista. Todo ello procede en realidad de una débil conciencia ciudadana sobre el periodo de la dictadura franquista y, en general, sobre la consideración cívica de los fascismos dentro de la sociedad española.

\section{El fascismo franquista}

La heterogeneidad interna del fascismo ha ocasionado problemas de definición, caracterización y análisis a los historiadores. Diversos autores se han empeñado en una clasificación de los rasgos «fascistas» más prominentes para posteriormente aplicarlos a diferentes situaciones. Esto es debido a que todos los fascismos presentaron características «singulares», de modo que sus mentores concibieron la construcción de su Estado como algo «original». En el caso portugués, Salazar señalaba que su dictadura se aproximaba a la «dictadura fascista» en el refuerzo de la autoridad, en la guerra declarada a los principios de la democracia, en su carácter marcadamente nacionalista y en sus preocupaciones de orden social. No obstante, se apartaba de su «cesarismo pagano» y de su ausencia de limitaciones jurídicas y morales para la obtención de los objetivos propuestos (Ferro, 1933: 74). Es decir, como afirmaba el propio Salazar, existían en aquel periodo sistemas políticos con semejanzas manifiestas, con puntos de contacto, pero en el proceso de realización y en la concepción del Estado y en la organización del apoyo político y civil del gobierno presentaban una serie de diferencias evidentes (Salazar, 1935) ${ }^{14}$.

${ }^{13}$ Declaraciones realizadas por el antiguo ministro del Interior y eurodiputado del Partido Popular, Jaime Mayor Oreja, La Voz de Galicia, 15 de octubre de 2007. Vid. cfr. Espinosa (2006: 205-253).

${ }^{14}$ Vid. Loff (2008: 32-50) para el asunto de las «peculiaridades nacionales» de cada modelo político dentro de ese nuevo orden constituido por el eurofascismo. 
Lo que hacían dictadores fascistas como Franco o Salazar, era situarse dentro del nuevo orden económico establecido en Europa a partir de la «revolución nacionalsocialista» en Alemania. El fascismo era visto en muchos casos como un fenómeno económico de carácter continental dentro de un estadio histórico propio del desarrollo europeo (Milward, 1970). El discurso y la práctica fascista se alzaron contra la práctica de los movimientos obreros jerarquizados ideológicamente a partir del marxismo. El contexto de gran agitación social del periodo 1917-1936 provocó que las clases dominantes en Europa Occidental se sintiesen amenazadas por la fuerza de ese creciente movimiento obrero. De hecho, el fascismo fue utilizado por la derecha para enfrentarse contra los movimientos populares no por su obrerismo, sino por su condición marxista. Las clases dominantes temían el poder que habían alcanzado las organizaciones de clase, de modo que su apuesta fue apoyar a los movimientos fascistas como contrapeso a los sistemas democráticos liberales o al comunismo revolucionario. El fascismo fue visto como un proceso histórico de superación de toda una serie de problemas y conflictos caracterizadores de una fase muy larga de la Historia europea (Loff, 2008: 35).

Las caracterizaciones sobre el fascismo más conocidas se centran en una serie de aspectos definitorios, que pueden ser el antimarxismo, el antiliberalismo, el anticonservadurismo, el caudillaje, el ejército de partido o milicias y el totalitarismo (Nolte, 1963); u otros como la creación de una nueva clase de hombre, el líder sobrehumano, la propaganda como mecanismo de glorificación, un nacionalismo extremo, la consecución de mejores materiales, la ordenación de la sociedad a través de nuevas organizaciones y la existencia de diversos grupos sociales subordinados al orden fascista (Malefakis, 2000) ${ }^{15}$. Tales criterios han sido considerados insuficientes por Navarro (2006: 129-130). En su opinión, además de no haberse explicitado con claridad los aspectos ideológicos fascistas de la dictadura española, se han ignorado otros realmente definitorios como "el racismo, la negación de la existencia de clases sociales portadoras

${ }^{15}$ Entre los estudios renovadores sobre la ideología fascista, conviene destacar los trabajos decisivos de Mosse (1974 y 1979), quien ha subrayado la importancia de la nacionalización de las masas y de la mística nacional; el de Linz (1988), que ha incidido en la importancia del hipernacionalismo; los trabajos de Sternhell bien individuales (1978 y 1983), bien colectivos, con Sznajder y Asheri (1994), en que se incorpora como rasgo básico el carácter revolucionario del fascismo; el estudio de Griffin (1993), quien concibe la ideología fascista como una forma palingenésica de ultranacionalismo populista; el de Eatwell (1995), quien ve el fascismo como una síntesis radical de aspectos procedentes de la izquierda y la derecha; o el trabajo de Gentile (2002), quien ha reafirmado lo que el fascismo tiene de religión laica, pensamiento mítico y mística de la nación. En general, en todos ellos son comunes para el fascismo los aspectos nacionalistas, palingenésicos, revolucionarios y antiliberales (Griffin, 1998: 14). 
de intereses estructuralmente antagónicos y un profundo anticomunismo" Son elementos claramente racistas del régimen franquista el racismo imperialista y su discurso y representación a través de hechos tan tangibles como la designación del día nacional como «Día de la Raza». En la obra del médico psiquiatra Antonio Vallejo Nájera (1937: 7), procedente de la ideología del tradicionalismo católico, se señaló el aumento del «cretinismo racial iniciado en las postrimerías de la dinastía austriaca, hallándonos al borde de la desaparición de la raza a partir del último heroico esfuerzo de la guerra napoleónica». Este psiquiatra sostenía que las ideas morales y culturales del pueblo tenían más influencia en la descendencia que las condiciones antropológicas (1937: 77) y, por ello, era defensor de una política racial basada en la moralización de las costumbres y en los valores espirituales de la raza hispana. La raza hispana se caracterizaba por rasgos biopsíquicos, acordes con los cristianos que construyeron ese sentido de «hispanidad $»^{17}$. No obstante, los problemas para la explicitación fascista del régimen franquista, por lo que tiene que ver con esta idea del racismo, están relacionados con la escasez de estudios en relación a la recepción del discurso fascista alemán dentro del franquismo e incluso a la contribución que este pudo hacer a la retórica de ese nuevo orden ${ }^{18}$.

Un hecho significativo es que diversos especialistas han hecho hincapié en el escaso carisma de Franco como una característica «no fascista» (Moradiellos, 2003: 15-17). De modo sorprendente, para dilucidar esa ausencia de carisma, se suele ocultar el «carácter sangriento» y de «limpieza selectiva» de la dictadura, un rasgo, en nuestra opinión, absolutamente relevante, que introduce la figura de Franco en una dimensión histórica particular ${ }^{19}$. Este aspecto eleva

${ }^{16}$ En cambio, en Núñez Seixas (2005: 22-23) se afirma que no hubo intención de "esbozar un racismo de corte más o menos biológico-genético como base de la nación que fuese más allá del antisemitismo cultural y religioso", aunque un poco más adelante acepta que ese antisemitismo retórico-discursivo pudiera contemplarse como un «racismo cultural», aunque no «biológico».

${ }^{17}$ Este médico fue director durante la guerra civil española de un Gabinete de Investigaciones Psicológicas de la Inspección de Campos de Concentración de Prisiones de Guerra. Sus trabajos con prisioneros del bando republicano reafirmaron sus tesis pseudocientíficas sobre la naturaleza psicosocial degenerativa e inferior de los «marxistas».

${ }_{18}$ Durante la Segunda Guerra Mundial, ciertos grupos de falangistas adoptaron la simbología nazi, contaron con la protección y el apoyo de la Embajada alemana y de sus servicios de información. También se produjeron algunos conatos de boicot a ciudadanos originarios de los países aliados. En Valencia, un grupo de falangistas formó un grupo clandestino de carácter propagandístico y coactivo (Núnez Seixas, 2005: 24).

${ }^{19}$ Según los datos que constan en el Sumario 53/2008 del Juzgado de Instrucción ${ }^{\circ} 5$ de la Audiencia Nacional de Madrid, conocido popularmente como «causa del franquismo», la represión franquista pudo costar entre 136.000 y 152.000 víctimas en el periodo que va desde 1936 a 1951, http://www.publico.es/resources/archivos/2008/11/18/1227007366976AUT 
la condición fascista de su régimen, pese a la supuesta condición grisácea de su personalidad. De hecho, como ha señalado Navarro (2006: 134), la propaganda se encargó de presentar a Franco como un «ser excepcional», tocado de rasgos sobrehumanos o divinos, al ser señalado por el «dedo de Dios» y colocado al lado de los grandes guerreros medievales de la historia de España (Tranche y Sánchez Biosca, 2000; Pereira, 2003; Sevillano Calero, 2003; Germán Fandiño, 2009; Casanova y Gil Andrés, 2009: 240). La política fascista de movilización de masas funcionó desde el principio, con las intermitencias propias de la coyuntura sociopolítica. Se hicieron campañas públicas de recatolización a través de misiones populares, peregrinaciones, consagraciones y misas en honor de «los caídos por Dios y por España». La exclusión de España de la ONU en agosto de 1946, la amenaza de retirar los embajadores de los Estados miembros de la capital española y la previsión de estudiar medidas si el régimen español no evolucionaba hacia formas democráticas, provocó una movilización de protesta contra la ONU y de apoyo a Franco en la plaza de Oriente de Madrid el 9 de diciembre de 1946. La concentración fue organizada por el gobierno, pero fue una manifestación que permitió calibrar los apoyos del régimen. Molinero (2005: 47) ha descrito la política de movilización popular del régimen franquista de esta manera: "El discurso social como mecanismo de generación de consenso fue paralelo durante la dictadura a un intento de movilización de la población, que no fue permanente pero sí suficiente para alcanzar el objetivo de transmitir solidez, así como escenificar el apoyo de las masas y la existencia de una comunidad nacional ordenada y entusiasta en torno a los símbolos y los mitos del régimen".

Otro de los elementos más empleados para dilucidar el carácter no fascista del franquismo es que el partido único, Falange Española Tradicionalista y de la JONS, no había sido una creación del dictador. En nuestra opinión, tal hecho es "irrelevante" para considerar el franquismo como fascista. Lo que interesa sobre este aspecto es que Franco se encargó de su unificación, de instrumentalizarlo, de liderarlo, de condicionarlo y de transformarlo en un movimiento fascista conocido como Movimiento Nacional. Navarro (2006: 135-137) ha señalado que este Movimiento, junto con el Ejército y la Iglesia mantuvieron más cohesión institucional que la que mostraron los bloques de

O\%20S.\%2053.08.pdf. Sumemos a ello los 500.000 exiliados, los 400.000 juicios militares, las 70.000 condenas a muerte (50.000 de ellas cumplidas), las 300.000 personas que fueron a parar a más de cien campos de concentración o a ciento noventa de trabajos forzados, los millares de inhabilitaciones de cargos públicos y de funcionarios, y los 30.000 niños secuestrados y entregados a familias del régimen. Vid. cfr. Casanova y Gil Andrés (2009: 232-240). 
poder conformados por Mussolini o Hitler. Navarro indica, como elemento sumamente ilustrativo, que ese «movimiento fascista español» tuvo presencia en las instituciones estatales tanto en forma externa a través de símbolos como a través de la representación formal que todos los funcionarios habían de asumir al jurar lealtad a los principios del Movimiento Nacional. Lo interesante de este acto era el significado interno del mismo, ya que implicaba la adhesión a «una red de intereses corporativistas y económicos utilizados con fines personales, revestida de una ideología sumamente adaptable», una situación relativamente similar a lo ocurrido en el nazismo alemán y en el fascismo italiano. Como ha señalado Muniesa (1996: 37-38), el Partido Único se construyó a partir de una afiliación masiva, porque eso permitía la supervivencia y las expectativas dentro de un futuro aparentemente negro para muchos, pero "las posibilidades eran múltiples, como en cualquier Estado totalitario". El carnet de falangista permitía hacer carrera dentro de la burocracia estatal o dentro del aparato de control de las relaciones laborales. Se potenció la figura del «intermediario» como personaje que contrabandeaba con información, pero que alargó infinitamente una red totalitaria de adeptos.

También la incorporación de elementos procedentes del catolicismo español y del nacionalismo imperialista introdujo una concepción «totalizante» en el discurso franquista, en el sentido de que había el objetivo de organizar la totalidad de las costumbres, de la vida social y de la vida cotidiana privada de las personas. Existió una homogeneidad dentro de la estructura de poder a pesar de que se mantuvieron diferencias latentes y abiertas entre diferentes sectores del régimen. Que el régimen sufriese una evolución en los treinta y nueve años de duración, de modo que remitiesen ciertos componentes fascistas establecidos durante la fase inicial no implica que al final del mismo, en 1975, no siguiese conservando sus rasgos básicos. En 1975, a la muerte de Franco, el rey Juan Carlos juró lealtad al Movimiento Nacional, postuló a un significativo cuadro del mismo, Adolfo Suárez, como conductor de las reformas políticas, y las elites fascistas de la dictadura o los poderes fácticos históricos permanecieron en la primera línea de ese proceso de cambio (Bar, 1997: 116), lo que constituye un «hecho diferencial de la historia española en el panorama europeo» (Muniesa, 1996: 157). Esas elites mostraron una capacidad de adaptación significativa a la nueva situación. Favorecía que esas elites hubiesen permanecido durante los últimos tiempos del régimen en una situación técnica de desideologización, unidas por los intereses que se distribuían en función del grado de participación o de proximidad a las estructuras de poder, al propio aparato fascista y a la comunión de discursos que compartían. La tesis de Navarro es que el régimen perdió «intensidad ideológica», pero no dejó de ser fascista. Se mantuvieron 
las señas de identidad hasta el fin de la dictadura, en forma de un "misticismo nacionalista exacerbado, racista, profundamente anticomunista". No en vano, señala este autor, las clases de «Espíritu Nacional» se impartieron en los centros de enseñanza hasta el curso 1975-1976.

\section{El componente totalitario del régimen franquista}

La condición totalitaria del régimen franquista también ha sido discutida por muchos especialistas (Moradiellos, 2004: 69-80), pero resulta evidente su presencia. La ideología fascista se introdujo en todos los ámbitos de la vida de los españoles. La Iglesia colaboró en ello. Una cuestión diferente son las luchas entre las diferentes familias del régimen en forma de ampliación o apropiación de áreas de influencia. La intención del franquismo era eliminar el laicismo procedente de la tradición anticlerical republicana, condicionar la vida privada de las personas y las relaciones interpersonales e imponer una conducta determinada en la totalidad de las dimensiones de la vida humana. El nivel de intervención fue enorme y el impacto de la represión psicológica y social aún está por determinar ${ }^{20}$. Navarro (2006: 141-142) afirma que el nivel de intrusión del franquismo fue mayor a los mostrados por los nazis y los fascistas italianos. Se optó por extender un nacionalcatolicismo que impregnó a casi la totalidad de los sectores sociales. Ello incluía una mezcla de racismo, imperialismo, militarismo y reaccionarismo. Las relaciones interpersonales se vieron condicionadas por la represión psicológica y sexual. Se utilizó un adoctrinamiento intensivo sustentado en el deseo de crear una nueva sociedad, con un nuevo discurso en prácticamente todos los órdenes de la vida. Como afirma Navarro, que los objetivos no se cumpliesen, no implica que en el diseño ideológico estuviese presente esa necesidad de construir una nueva sociedad. Se pusieron medios para ello, no lograrlo en su totalidad implica un análisis sobre el fracaso de tales medios, pero no pone en duda las intenciones y los objetivos.

La consideración fascista y totalitaria del régimen franquista ha sido empequeñecida en la historiografía sobre todo a partir de una cierto miramiento académico con la etapa autoritaria de desarrollismo tecnocrático y expansión

${ }^{20}$ Nos referimos a los millares de personas que vivieron intimidados por la presencia de las milicias patrióticas, por la contemplación pública de los castigos, por las multas y sanciones, por la publicidad de los consejos de guerra y fusilamientos, por las visitas de falangistas y guardias a los domicilios particulares, por las persecuciones continuas a los familiares de los desafectos, o por la simple necesidad de sobrevivir económicamente. Vid. Mir (1999), Richards (1999) y Vega (2005: 239-244). 
económica entre 1959 y $1969^{21}$. En nuestra opinión, conviene cuestionar la marginalización de esa consideración fascista durante ese periodo, cuando los denominados «tecnócratas» del régimen, todos procedentes del Opus Dei, habían mantenido una sintonía ideológica con las posiciones básicas del franquismo, es decir, con la intolerancia religiosa, la percepción jerárquica de la sociedad, el elitismo, el autoritarismo, el fanatismo y el control psicológico sobre sus miembros. No obstante, el Opus Dei era una organización minoritaria tras la guerra civil. Su expansión dentro de ciertos sectores de la sociedad española se remonta a la promulgación de la Ley de Ordenación Universitaria de 1943. A través de ella, la Universidad tuvo que adaptarse a los dogmas católicos, a las normas del Derecho Canónico y a los principios del Movimiento. El terreno educativo se consideró vital para los poderes católicos. A él se aplicó durante doce años (1939-1951), el ministro José Ibáñez Martín. Fue el encargado de depurar a los profesionales de la enseñanza, de catolizar la enseñanza y de beneficiar a las escuelas propiedad de la Iglesia. Además, transformó el Consejo Superior de Investigaciones Científicas en un vivero de cátedras universitarias afines al Opus Dei (Casanova y Gil Andrés, 2009: 249-250). Muchos miembros del Opus Dei ocuparon altos puestos de la administración entre 1957 y 1974. Introdujeron una política económica dirigida a la exportación, a la acomodación de España dentro del sistema capitalista mundial y a la consolidación de los intereses del gran capital. En general, siguieron muchas de las directrices marcadas por el Fondo Monetario Internacional y los modelos de planificación franceses, porque realmente hacia finales de la década de los 50 el país estaba en quiebra técnica. Por supuesto, no mostraron ningún deseo de introducir mejoras democráticas a nivel político y su plan económico se vio favorecido por la coyuntura internacional, en especial por las sólidas economías de los países occidentales, y por los cambios estructurales que evolucionaron hacia la industrialización y los servicios.

No obstante, se sigue manteniendo en la historiografía española con bastante solidez la tesis de considerar al Opus y a los tecnócratas vinculados a esa organización como una especie de germen predemocrático que propició una evolución del régimen franquista. Se olvida, sin embargo, que la política económica de los tecnócratas careció de planificación, presentó múltiples defectos y se favoreció de la maquinaria propagandística del régimen. La consecuencia más significativa de esos quince años de política económica de los tecnócratas fue la consolidación de un Estado español absolutamente

${ }^{21}$ Para comprender desde el punto de vista económico ese periodo conviene consultar Barciela, López, Melgarejo y Miranda (2001). 
desequilibrado, de modo que se había producido una concentración poblacional en ciertos territorios y la mitad de la renta se producía en la décima parte del país ${ }^{22}$. También fueron los miembros del Opus Dei los creadores del Tribunal de Orden Público en 1963, encargado del encarcelamiento y enjuiciamiento de la nueva oposición antifranquista de los años sesenta. O los responsables de la eliminación de cualquier corriente crítica dentro de la Universidad española. Debajo de la apariencia de un pragmatismo técnico y objetivo, los miembros del Opus Dei mantuvieron la tensión de evitar la descomposición totalizadora del régimen franquista. Las diferentes familias del franquismo estaban convencidas de la durabilidad del sistema una vez consumada la desaparición del dictador. La consolidación de Juan Carlos de Borbón como sucesor a la jefatura del Estado con el título de rey de España en 1969 respondía a ese objetivo de permanencia como fin del proceso de institucionalización del régimen. Solamente las elites políticas partidarias de la abertura política y la resistencia mostrada por las fuerzas antifranquistas introdujeron un cambio de rumbo a la política reformista mantenida por los elementos continuistas del régimen anterior. Además, la influencia de la Revolución portuguesa de abril de 1974 actuó como un mecanismo de referencia para los diferentes sectores involucrados en el proceso de cambio, aunque tal acontecimiento no haya recibido la atención requerida por parte de la historiografía española (Sánchez Cervelló, 1993). Posiblemente, la resistencia en la sociedad española a usar el término «fascista» para referirse al régimen franquista tiene que ver con el complejo proceso de negociación que se produjo durante la Transición española. La correlación de fuerzas entre el poder procedente del franquismo y los partidos u organizaciones de izquierda terminó por imponer también un discurso con un cierto patrón consensuado, que reproducía el desequilibrio presente en ese proceso de negociación. De ese modo, se impuso el término «franquismo» en lugar de «fascismo» para referirse al régimen político que había durado casi cuarenta años. La primera denominación mantenía una connotación de neutralidad asumible por muchos sectores que habían crecido, vivido y trabajado durante ese periodo. De algún modo, esa denominación contenía un mayor poder de inclusión, frente a la

${ }^{22}$ Durante el periodo 1960-1970 el país creció a un ritmo del 7\% y se produjo un cambio estructural que lo hizo transformarse en un país industrializado y de servicios. A ello hay que sumarle la mejora de la actividad agraria, el crecimiento demográfico, la intensa urbanización, los crecimientos de la renta y de la esperanza media de vida, de infraestructuras en las viviendas y de automóviles. Sin embargo, en otros aspectos el país demostraba estar aún casi en el siglo XIX, como en el fracaso de la renovación del sistema fiscal, caracterizado por un fraude generalizado y una falta de equidad social en las cargas tributarias. 
denominación de «fascismo» que introducía una connotación estigmatizadora y excluyente para muchos ciudadanos.

\section{La memoria ciudadana del fascismo español}

Todo este proceso de revisión del pasado franquista ha anulado la memoria de la Segunda República española (1931-1936) como una memoria «democrática» y como un periodo de significativos avances sociales. Los partidos políticos de ideario republicano han eliminado también tal referencia de su memoria colectiva (Vinyes, 2009). Aunque esa memoria republicana está unida a una memoria de progreso y a una memoria mayoritariamente «comunista»o «socialista», las fuerzas políticas herederas de tal memoria no se han atrevido a recuperarla hasta hace muy poco tiempo y, en términos generales, lo han hecho de modo titubeante ${ }^{23}$. Los experimentos llevados a cabo en algunos de los campos de concentración durante el franquismo con la intención de purificar la raza española y de eliminar el «gen rojo» fueron un precedente de los posteriores experimentos realizados por los nazis, pero además fueron una manifestación de la introducción de una memoria repulsiva sobre la militancia de izquierda en muchos ciudadanos españoles ${ }^{24}$.

La estigmatización de la memoria de izquierda y republicana ha hecho desaparecer de la memoria colectiva las propuestas de avance democrático que supuso la Segunda República o, al menos, han condicionado la interpretación sobre ellas: el recorte de privilegios de los poderes fácticos y corporativos que limitaron totalmente la vida socioeconómica del país, la introducción de la escuela pública, la Seguridad Social, la reforma agraria, el divorcio, el aborto, las reformas militares, el derecho a sindicarse, el respeto a la concepción plurinacional del Estado, el sufragio universal. Esa estigmatización ha minimizado socialmente el sentido del golpe militar de 1936, los apoyos que tal decisión atrajo (banca, Iglesia, terratenientes, burguesía conservadora, Hitler, Mussolini) y la categórica acción de las clases populares en la defensa del gobierno republicano.

${ }^{23}$ En general, se puede afirmar casi taxativamente que no existe ninguna memoria republicana en la sociedad española actual.

${ }^{24}$ Vid. Sevillano (2007: 87-105). En algunos autores, esa corriente social anticomunista es reducida a una especie de «barniz unificador que hacia afuera limaba diferencias en la coalición insurgente de 1936» (Núñez Seixas, 2005: 23). No tenemos ningún estudio sobre la relación e influencia de la corriente anticomunista propia del franquismo y la baja consideración social actual de las organizaciones comunistas en España. 
Durante los últimos treinta y cinco años, las fuerzas políticas han preferido incidir más en la memoria ciudadana de la Transición (1975-1982) como un periodo de recomposición democrática y, de alguna manera, como un periodo fundacional. Navarro (2006: 159 y ss.) sostiene que la Transición española no fue especialmente ejemplar. En su opinión, ello fue debido al predominio de las fuerzas conservadoras y a la debilidad de las fuerzas de izquierda. La decisión de amnistiar los crímenes de la dictadura franquista respondió a esa correlación, por mucho que también se amnistiasen a los militantes antifranquistas, cuyo número de delitos, y su condición, era cuantiosamente menor a los cometidos por muchos funcionarios y políticos de la dictadura ${ }^{25}$. Del mismo modo también se produjo un desigual reparto en la intervención social sobre la memoria del pasado y, en concreto, sobre la memoria del fascismo español. Se silenció la versión de las organizaciones de izquierdas sobre el pasado y se difundió la producida por las fuerzas conservadoras. Se equipararon las responsabilidades históricas sobre los asesinatos producidos durante la guerra civil y el franquismo, de modo que no se produjo ninguna distinción entre ambos periodos, y así permanece desde entonces. Se hizo desaparecer el componente totalitario del régimen franquista y se redefinió como un «régimen autoritario conservador» que surgió como consecuencia de un «alzamiento» militar que consiguió acabar con el caos de la Segunda República. Finalmente, se estipuló como comprensible desde el ámbito de la memoria ciudadana aceptar que la dictadura franquista evolucionó hacia un régimen modernizador de carácter represivo que terminó convertido en una democracia monárquica.

Esta interpretación de la dictadura franquista ha omitido aspectos esenciales de la política fascista, entre otros los costes económicos y sociales producidos en la sociedad española a lo largo del periodo de 1939-1975. En parte tiene que ver con la mentalidad fascista que organizó el país durante la primera década de la dictadura, pero que pervivió más allá de esa fecha. En 1950, la renta estaba por debajo de la de 1930, la producción agraria estaba en crisis absoluta y la producción industrial estaba por debajo de los niveles de la década de 1930. El proceso de modernización económica y socioprofesional que se había iniciado a principios del siglo XX retrocedió totalmente. Una prueba palpable de ello es el actual atraso que mantiene España en relación a otros países europeos.

${ }^{25}$ Además, la ley de amnistía de 1977 estaba pensada para amnistiar a los militantes antifranquistas no a los cuadros del régimen franquista. 
Las políticas económicas del franquismo respondían a la visión que las elites empresariales mantenían sobre la evolución del país ${ }^{26}$, de modo que se hizo necesario reprimir a las clases populares, porque no de otra manera se pudieron imponer las decisiones económicas de los años sesenta ${ }^{27}$. La extensión de la pobreza obligó a que un treinta y cinco por ciento de la clase trabajadora se viese en la obligación de emigrar a otros países, en términos globales un diez por centro de la población activa entre 1960 y $1972^{28}$. Las remesas enviadas por los emigrantes, las inversiones extranjeras (sobre todo, de Estados Unidos, Alemania, Suiza y Gran Bretaña) y las divisas que entraron con el turismo de masas favorecieron un desarrollo absolutamente desequilibrado durante el tardofranquismo. Fue en ese periodo que el régimen se encontró con la resistencia de una nueva clase trabajadora, con obreros más cualificados y especializados profesionalmente que habían decidido organizarse y defender sus derechos laborales. Serán los protagonistas de la conflictividad sociolaboral de los últimos quince años del franquismo. Sin embargo, en los últimos años del régimen franquista, la represión volvió a recrudecerse, con varios trabajadores muertos, muchos represaliados y varios militantes antifranquistas asesinados.

La dura represión de la dictadura terminó con las tradiciones sindicales y políticas. No se ha estudiado demasiado este asunto, pero los trabajadores afrontaron los conflictos de 1960 sin referencias propias de una tradición, porque la cultura obrera había sido totalmente eliminada. De hecho, el régimen franquista no permitió que el nuevo movimiento obrero creciese lo suficiente como para que llegase a convertirse en una fuerza de ámbito estatal. Ello a pesar de que el nivel de conflictividad de los últimos años de la dictadura hacía pensar en otra situación. Durante los años de gobierno socialista (1982-1996) se completó el proceso de aniquilación de la memoria obrera y de izquierda del siglo XX, aunque en ese proceso participaron varias de las fuerzas políticas parlamentarias. En ese proceso, se incluyó la eliminación de la vida pública de la memoria de los represaliados republicanos y de izquierda.

${ }^{26}$ En el periodo 1939-1945, los cinco grandes bancos españoles (Central, Banesto, Hispano-Americano, Bilbao y Vizcaya) crecieron el $700 \%$.

${ }^{27}$ Las condiciones laborales de las clases populares tenían su base en el proceso de fascistización de 1936-1939 a partir del Fuero del Trabajo. Los trabajadores eran productores disciplinados, fieles y subordinados al jefe de la empresa, quien mantenía una dirección casi militarizada. La tasa de explotación de los trabajadores era altísima. Los salarios eran míseros. Durante los primeros quince años de la dictadura no hubo posibilidad de actuar colectivamente. Los trabajadores no contaron con medidas de previsión social hasta muy avanzada la dictadura. Las huelgas estuvieron ilegalizadas y la disciplina laboral era sumamente férrea.

${ }^{28}$ Además, del enorme éxodo rural a las ciudades que fue masivo desde los años 40 . 
Pero la memoria tiene un difícil control. La amnesia tiene a inundar su territorio más veces de lo previsto. En España ha sido muy habitual. Un conocido politólogo español ha descrito tal proceso como una habilidad propia de los españoles para lanzar al olvido la memoria de los traumas de la guerra civil y de la dictadura (Juliá, 2003). Sin embargo, el recambio generacional ha producido un mecanismo habitual en muchas sociedades. La generación que ronda ahora los cuarenta años ha construido un nuevo discurso sobre la dictadura franquista. Se ha subrayado su carácter represivo, fascista y sangriento, con la intención de construir un relato común sobre el «genocidio franquista», un genocidio atroz hasta 1951 y carente de piedad hasta la muerte del dictador ${ }^{29}$.

El desarrollo de los derechos humanos ha sido fundamental para revisar los procesos de transición política en varios países, entre ellos España. Su influencia ha permitido considerar la conveniencia de establecer un reconocimiento efectivo sobre las víctimas de la represión franquista a partir de algunas decisiones legislativas por parte del gobierno español ${ }^{30}$. Sin embargo, esa memoria ciudadana no ha establecido una política clara de reparación de las injusticias cometidas durante la dictadura franquista (responsabilidades políticas, institucionales, empresariales, etc.) ni tampoco ha conseguido establecer una clara relación entre el antifranquismo y la democracia. En 2008, un grupo significativo de ciudadanos han sido capaces de denunciar jurídicamente los crímenes del franquismo. Parece que un asunto que estaba reservado exclusivamente a los historiadores ha pasado ahora al mundo de los juristas. También supone un proceso de equiparación con otras democracias occidentales que decidieron hace años revisar sus pasados traumáticos. Subyace en esas dinámicas de reflexión sobre el pasado una intención de construir sociedades más cívicas, más justas y más democráticas.

\section{Referencias bibliográficas}

Aguilar, P. - Políticas de la memoria y memorias de la política, Madrid, Alianza, 2008.

Aróstegui, J., "Los componentes sociales y políticos”, en M. Tuñón de Lara y otros, La guerra civil española. 50 años después, Barcelona, Labor, 1986, pp. 45-122.

${ }^{29}$ Recordemos que Franco llegó a fusilar a cinco antifranquistas en septiembre de 1975 pese a la oposición interna e internacional.

${ }^{30}$ Ley 52/2007, de 26 de diciembre, por la que se reconocen y amplían derechos y se establecen medidas en favor de quienes padecieron persecución o violencia durante la guerra civil y la dictadura. (BOE $\left.\mathrm{n}^{\circ} 310,27-\mathrm{Dic}-2007\right)$. 
Bar, A., "Spain: A Prime Ministerial Government", in J. Blondel e F. MullerRommel (dirs.), Cabinets in Western Europe, New York, Saint Martin Press, pp. 116-135.

Barciela, C.; López, M. I.; Melgarejo, J.; Miranda, J.A., La España de Franco (1936-1975). Economía, Madrid, Síntesis, 2001.

Casanova, J., "La sombra del franquismo: ignorar la historia y huir del pasado", en J. Casanova, A. Cenarro, J. Cifuentes, M. P. Maluenda y M. P. Salomón, El pasado oculto. Fascismo y violencia en Aragón, 1936-1939, Madrid, Siglo XXI, 1992, pp. 1-28.

Casanova, J. y Gil Andrés, C., Historia de España en el siglo XX, Barcelona, Ariel, 2009.

Eatwell, R., Fascism. A History, London, Chatto and Windus, 1995.

Elorza, A., "Mitos y simbología de una dictadura", Bulletin d'Historie Contemporaine de l'Espagne, 24, 1996, pp. 47-68.

Espinosa, F., Contra el olvido. Historia y memoria de la guerra civil. Barcelona, Crítica, 2006.

Ferrando Badía, J., El régimen de Franco. Un enfoque político-jurídico, Madrid, Tecnos, 1984.

Ferro, António, Salazar. O homem e a sua obra, Lisboa, Emprêsa Nacional de Publicidade, 1933.

Fusi, J. P., Franco. Autoritarismo y poder personal, Madrid, El País, 1985.

Gentile, E., Fascismo. Storia e interpretazione, Roma-Bari, Laterza \& Figli Spa, 2002.

Giner, S., Sociología, Barcelona, Península, 1985.

Griffin, R., The Nature of Fascism, London/New York, Routledge, 1993.

Griffin, R. (ed.), International Fascism. Theories, Causes and the New Consensus, London, Arnold, 1998.

Hernández Sandoica, E., Los fascismos europeos, Madrid, Istmo, 1992.

Germán Fandiño, R., El baluarte de la buena conciencia; prensa, propaganda y sociedad en La Rioja del Franquismo, Logroño, Instituto de Estudios Riojanos, 2009.

Juliá, S., Historia económica y social moderna y contemporánea de España. II. Siglo XX, Madrid, UNED, 1996.

Juliá, S., "Echar al olvido: Memoria y Amnistía en la Transición", Claves de razón práctica, $\mathrm{n}^{\circ} 129,2003$, pp. 14-25.

Loff, M., O nosso século é fascista.O mundo visto por Salazar e Franco (1936-1945), Lisboa, Campo das Letras, 2008. 
Luebbert, G. M., Liberalismo, fascismo o socialdemocracia. Clases sociales y orígenes políticos de los regímenes de la Europa de entreguerras, Zaragoza, Prensas Universitarias de Zaragoza, 1997.

Malefakis, E., “¿Fue fascista el régimen franquista?” en García Delgado, J. L. (coord.), Franquismo. El juicio de la historia, Madrid, Ediciones Temas de Hoy, 2000, pp. 11-55.

Miguel,A. de., Sociología del franquismo. Análisis ideológico de los ministros de Franco, Barcelona, Euros, 1975.

Molinero, C., La captación de las masas. Política social y propaganda en el régimen franquista, Madrid, Cátedra, 2005.

Muniesa, B., Dictadura y monarquía en España. De 1939 hasta la actualidad, Barcelona, Ariel, 1996.

Linz Storch de Gracia, J. J., “An Authoritarian Regime: Spain”, en E. Allardt e Y.Littunen (eds.), Cleavages, Ideologies and Party Systems. Contributions to Comparative Political Sociology, Helsinki, 1964.

Linz Storch de Gracia, J. J., "From Falange to Movimiento Organization", en Huttington y Moore, Authoritarian Politics in Modern Society, Nueva York, 1970.

Linz Storch de Gracia, J. J., "Opposition in and under an Authoritarian Regime: The Case of Spain", en R. Dahl, Regimes and Oppositions, Nueva York, Yale University Press, 1973.

Linz Storch de Gracia, J. J., "Una teoría del régimen autoritario. El caso de España”, en M. Fraga, J. Velarde y S. del Campo (dirs.), La España de los años 70, III, El Estado y la Política. I, Madrid, Moneda y Crédito, 1978, pp. 1468-1531.

Linz Storch de Gracia, J. J., "Una teoría del régimen autoritario. El caso de España", en S. G. Payne, Política y sociedad en la España del siglo XX, Madrid, Akal, 1978, pp. 205-263.

Linz Storch de Gracia, J. J., "Some Notes Toward a Comparative Study of Fascism in Sociological Historical Perspective", en Walter Laqueur (ed.), Fascism. A reader's guide, Aldshort, Wilwood House, pp. 3-121.

Miguel, A. de y Oltra, B., "Bonapartismo y catolicismo. Una hipótesis sobre los orígenes del franquismo", Papers. Revista de Sociología, 8: 53-102.

Milward, A. S., The New Order and the French Economy, Oxford, Oxford University Press/Clarendon Press, 1970.

Mir, C., "Coacción legal y oposición interior", El primer franquismo. Ayer, $\mathrm{n}^{\mathrm{o}} 33,1999$.

Moradiellos, Enrique, La España de Franco (1939-1975). Política y sociedad, Madrid, Editorial Síntesis, 2003. 